\title{
Pyrolysis products of uncoated printing and writing paper of $\mathrm{MSW}^{\text {is }}$
}

\author{
Chao-Hsiung $\mathrm{Wu}^{\mathrm{a}, *}$, Ching-Yuan Chang ${ }^{\mathrm{b}}$, Chao-Heng Tseng ${ }^{\mathrm{c}}$ \\ a Department of Environmental Engineering, Da-Yeh University, Chang-Hwa 515, Taiwan, ROC \\ ${ }^{\mathrm{b}}$ Graduate Institute of Environmental Engineering, National Taiwan University, Taipei 106, Taiwan, ROC \\ 'Department of Civil Engineering, National Taipei University of Technology, Taipei 106, Taiwan, ROC
}

Available online 13 November 2001

\begin{abstract}
Uncoated printing and writing paper, one of the principal waste papers in Taiwan, was pyrolyzed with a thermogravimetric analysis (TGA) reaction system. The pyrolysis experiments were carried out in nitrogen environment at a constant heating rate of $5 \mathrm{~K} \mathrm{~min}^{-1}$. The gaseous products and the residues were collected at room temperature $(300 \mathrm{~K})$ and analyzed by gas chromatography $(\mathrm{GC})$ and elemental analyzer, respectively. The major gaseous products investigated included non-hydrocarbons $\left(\mathrm{H}_{2}, \mathrm{CO}, \mathrm{CO}_{2}\right.$, and $\left.\mathrm{H}_{2} \mathrm{O}\right)$ and hydrocarbons $\left(\mathrm{C}_{1-3}, \mathrm{C}_{4}, \mathrm{C}_{5}\right.$, $\mathrm{C}_{6}$, 1-ring, $\mathrm{C}_{10-12}$, levoglucosan, $\mathrm{C}_{13-15}$, and $\mathrm{C}_{16-18}$ ). The cumulated masses and the instantaneous concentrations of gaseous products were obtained under the experimental conditions. The yields of non-hydrocarbon gases and of hydrocarbon gases were about 10.46 and $0.49 \%$ at $623 \mathrm{~K}, 33.68$ and $0.89 \%$ at $700 \mathrm{~K}, 64.52$ and $1.05 \%$ at $788 \mathrm{~K}$, and 79.10 and $1.63 \%$ at $938 \mathrm{~K}$, respectively. The estimation of the mass of tar, yielded at various pyrolysis temperatures was also made. The results of this study might be useful for the design of pyrolysis process as well as for determining the pyrolysis mechanisms of the uncoated printing and writing paper. (c) 2001 Elsevier Science Ltd. All rights reserved.
\end{abstract}

Keywords: Paper; Pyrolysis products; Thermogravimetric analysis

\section{Introduction}

The disposal of municipal solid waste (MSW) has become an increasingly intricate and costly problem because of the decrease in the available space for landfills and the growing concern about the living environment. Some studies and reviewed literature indicated that a proper thermal pyrolysis method might be used to resolve the disposal problems and make an energy conversion from MSW [1-6]. Typically, on a dry basis, MSW consisted of paper $(28.95 \%)$, cellulosic cloth $(8.11 \%)$, yard waste $(3.10 \%)$, food $(23.18 \%)$, plastic $(19.59 \%)$, leather and rubber $(0.43 \%)$, metals $(7.89 \%)$, glass $(6.98 \%)$, and ceramic, earthen materials and miscellaneous $(1.77 \%)$ in Taiwan [7]. Since the waste uncoated printing and writing paper contained a high calorific value of about $12,500 \mathrm{~kJ} \mathrm{~kg}^{-1}$ on a dry basis, its conversion to marketable fuels has become a noble goal from not only an economic, but also from an environmental standpoint.

Studies on the pyrolysis of cellulosic materials have been performed by many researchers. These studies were concerned mostly about the thermal degradation of pure cellulose and focused on the analyses of products, the effects

\footnotetext{
* Corresponding author.

E-mail address: chwu@mail.dyu.edu.tw (C.-H. Wu).

Published first on the web via Fuelfirst.com-http://www.fuelfirst.com
}

of reaction conditions, the mechanisms of reactions and the pyrolysis kinetics etc. From the experimental results by Fairbridge et al. [8] and Shafizadeh and Bradbury [9], for example, it was concluded that the rate of pyrolysis of cellulose in air might be enhanced by molecular oxygen in radical interactions at low temperature and considered to be independent of the oxidative reaction at high temperature. Antal et al. [10] investigated the kinetics of cellulose pyrolysis in steam and nitrogen. In their results, the presence of steam in the pyrolysis medium was found to have no measurable effect on cellulose pyrolysis. Simkovic et al. [11] examined the effects of additives and molecular mass of samples on the pyrolysis of cellulose. The results indicated that, in the case with the catalytic influence of $\mathrm{NaOH}$ on the cellulose thermolysis, the formation of gaseous products in the 523-623 $\mathrm{K}$ temperature range increased, and a greater amount of residue was formed at $623-673 \mathrm{~K}$ as compared to that with non-catalytic thermolysis. The molecular mass of samples did not influence the activation energy of gasification. However, Calahorra et al. [12] reported that the thermal stability increased as the molecular mass increased, and the cellulose pyrolysis process cannot be described as having a single value of activation energy during the entire pyrolysis range. Gullett and Smith [13] performed the thermal decomposition rate of pelletized cellulose cylinders in a laboratory furnace so as to simulate 
the pyrolytic/combustion behavior of pelletized refusederived fuel (RDF) at 588-1073 K. Also, a number of kinetic models about the pyrolysis of cellulose were reported in the literature [14-16]. Bradbury et al. [14] studied the pyrolysis of cellulose at low pressure (1.5 Torr) and proposed a three reaction model. In their model, it was assumed that an 'initiation reaction' led to the formation of an 'active cellulose' which subsequently decomposed via two competitive first-order reactions: one yielding volatiles and the other yielding char and a gaseous fraction. Agrawal [15] also proposed a threereaction model to simulate the pyrolysis behavior of cellulose and to predict the product yields of tars, chars and gases over $523-633 \mathrm{~K}$ temperature range. But in his model, Agrawal assumed that the cellulose decomposed to tars, chars and gaseous products via three competitive first-order reactions. A modified Kilzer-Broido (K-B) model [17] was also proposed by Agrawal [16] to describe the pyrolysis of cellulose at low temperature $(<573 \mathrm{~K})$. According to this model, cellulose decomposed via two competitive reactions, a dehydration reaction to form anhydrocellulose and a depolymerization reaction to form levoglucosan. Anhydrocellulose later decomposed to chars and gaseous products via two competitive reactions. The results indicated that the modified $\mathrm{K}-\mathrm{B}$ model was able to describe the pyrolysis of cellulose and more acceptable than the three-reaction model in predicting the mass loss and product yields. A simplified two-reaction model was proposed by Chang et al. [18] to illustrate the kinetic behavior of the pyrolysis of uncoated printing and writing paper over $450-850 \mathrm{~K}$ temperature range. The corresponding activation energies, preexponential factors, and reaction orders were determined in the experimental conditions. In other studies, some investigators have used thermogravimetry to examine the degradation kinetics of newsprint in air and nitrogen [19] and to explore the effects of acid washing on the pyrolysis products [20]. The results of previous studies provided some knowledge of determining the pyrolysis kinetics and products of cellulosic materials but they have not provided the related data about the pyrolysis products distribution of uncoated printing and writing paper of MSW.

Thus the aim of the present work is to deal with uncoated printing and writing paper of MSW with a view of providing the major gaseous products distribution as well as the variations of cumulated masses of gaseous products, residues, and estimated tar with pyrolysis temperature. The pyrolysis of uncoated printing and writing paper was studied by the thermal gravimetric analysis (TGA) reaction system at a constant heating rate of $5 \mathrm{~K} \mathrm{~min}^{-1}$. The experiments were carried out over a wide temperature range (450-950 K) and in the absence of gasifying agents. Nitrogen was used as the carrier gas. The gaseous products and the residues were collected at room temperature (300 K) and analyzed by gas chromatography (GC) and elemental analyzer. All these results are useful for determining the pyrolysis mechanisms and for applying the pyrolytic treatment of the uncoated printing and writing paper of MSW.

\section{Experimental}

\subsection{Materials}

Commercial-grade uncoated printing and writing paper was used in this study. It was supplied by the Yuen Foong Yu Co. Ltd of Taiwan, with the properties as described previously [18]. The nitrogen was purchased from the Ching Feng Harng Co. Ltd, of Taiwan, and had a purity of $99.9999 \%$.

\subsection{Pyrolysis apparatus and procedures}

The experiments for the pyrolysis of uncoated printing and writing paper were carried out with a TGA reaction system [18]. The electrical balance (Cahn-1000, USA; with $0.001 \mathrm{mg}$ readability) was used. A sample of known mass $(20 \pm 0.5 \mathrm{mg}$ ) was placed on a small quartz disk (with $2 \mathrm{~cm}$ diameter and $1 \mathrm{~mm}$ thickness). The disk was hung on the suspension wire (made of platinum with $0.18 \mathrm{~mm}$ diameter) of the balance and enclosed in a quartz shell and tube reactor. The outer shell was $27 \mathrm{~cm}$ long with a $3.8 \mathrm{~cm}$ inside diameter. The inner tube was $22 \mathrm{~cm}$ long with a $1.2 \mathrm{~cm}$ inside diameter. The nitrogen at a high flow rate was first introduced into the rear channel of the balance protector for $1 \mathrm{~h}$ to purge out the residual oxygen. It was then adjusted to the desired flow rate $\left(50 \mathrm{~cm}^{3} \mathrm{~min}^{-1}\right.$ at $300 \mathrm{~K}$ and $1 \mathrm{~atm}$, controlled by a Cole-Parmer N062-01ST rotameter) and switched over to the inner tube of the reactor. After about $0.5 \mathrm{~h}$, the reactor was placed in the furnace (HAS 100/250G with $1280 \mathrm{~W}$ ), which had been pre-set to a specified heating rate $\left(5 \mathrm{~K} \mathrm{~min}^{-1}\right)$. When the control units (Eurotherm 815S with RS232 interface) were all ready, the experimental run of pyrolysis was begun. At the same time, the variations of the mass of the sample and of the reaction temperature (probed with a K-type thermocouple) during the entire pyrolysis process were recorded at time intervals of $10 \mathrm{~s}$ by the data-processing unit (IBM PC-AT 586 with RS232 interface). The pyrolysis process was operated under atmospheric pressure. The gaseous products and the residues were collected at some specified temperature ranges (or temperatures) and cooled to room temperature (300 K). The gaseous products and the residues were analyzed by GC and by elemental analyzer, respectively.

\subsection{Sampling and analysis of gaseous products}

\subsubsection{Sampling}

The gaseous products were collected at the exit of reactor. The discrete sampling and the cumulated gas sampling methods were employed to collect the gaseous products. For the discrete sampling method, the gaseous products were collected in the $1 \mathrm{dm}^{3}$ sampling bags for the temperatures of $475-950 \mathrm{~K}$ in $25 \mathrm{~K}$ increments. The instantaneous concentrations of gaseous products at the pyrolysis temperatures of 488-938 $\mathrm{K}$ in $25 \mathrm{~K}$ increments shown in Tables 4 and 5 are corresponding to above temperature ranges, 
respectively. For the cumulated gas sampling method, the cumulated gaseous products, corresponding to the principal reaction temperature range $(475-950 \mathrm{~K})$ were collected in a $5 \mathrm{dm}^{3}$ sampling bag.

\subsubsection{Analysis}

The Varian chromatography, equipped with an INCOS 50 B mass spectrometer detector (MSD) and a Supelco SPB-1 capillary column was used to identify some major components in the gaseous products. For the analysis of hydrocarbon gases, a China Chromatography 8900 GC, equipped with a flame ionization detector (FID) and a Supelco fused silica capillary column $(30 \mathrm{~m}, 0.53 \mathrm{~mm}$ inside diameter, $1.5 \mu \mathrm{m}$ film thickness) was used. An integrator from Hewlett-Packard (HP 3395) was connected to the GC for graphing and integrating purposes. The conditions for analyzing hydrocarbon gases were set as follows: injector temperature $473 \mathrm{~K}$, detector temperature $523 \mathrm{~K}$, column temperature (following the sampling injection) being held at $308 \mathrm{~K}$ for $3 \mathrm{~min}$, nitrogen carrier gas flow rate $10 \mathrm{~cm}^{3} \mathrm{~min}^{-1}$, nitrogen makeup gas $30 \mathrm{~cm}^{3} \mathrm{~min}^{-1}$, sample volume $0.5 \mathrm{~cm}^{3}$. For the analysis of non-hydrocarbon gases $\left(\mathrm{H}_{2}, \mathrm{CO}\right.$, and $\left.\mathrm{CO}_{2}\right)$, a China Chromatography $8900 \mathrm{GC}$, equipped with a thermal conductivity detector (TCD) and a Supelco packing column (60/80 carbonxen$1000,4.57 \mathrm{~m}, 2.1 \mathrm{~mm}$ inside diameter) was used. An integrator from Hewlett-Packard (HP 3396) was connected to the GC for graphing and integrating purposes. The conditions for analyzing $\mathrm{H}_{2}, \mathrm{CO}$, and $\mathrm{CO}_{2}$ were set as follows: injector temperature $393 \mathrm{~K}$, detector temperature $333 \mathrm{~K}$, column temperature (following the sampling injection) being held at $308 \mathrm{~K}$ for $8 \mathrm{~min}$, helium carrier gas flow rate $25 \mathrm{~cm}^{3} \mathrm{~min}^{-1}$ for A and B columns, sample volume $2 \mathrm{~cm}^{3}$. The purity of gas standards was $99.9999 \%$ for $\mathrm{N}_{2}, 99.9 \%$ for $\mathrm{CO}_{2}, 99.7 \%$ for $\mathrm{CO}$, and $99 \%$ for $\mathrm{H}_{2}$, and $100 \mathrm{ppm}$ for $\mathrm{C}_{1}-$ $\mathrm{C}_{6}$ in $\mathrm{N}_{2}$, respectively. The retention times of standards used for analyzing the concentrations of $\mathrm{HCs}$ are listed in Table 1. The concentration of $\mathrm{H}_{2} \mathrm{O}$ in the gaseous products stream was detected by the psychrometer (HT-3003, Lutron).

\subsection{Sampling and analysis of residues}

\subsubsection{Sampling}

The mass of used sample for the experiments of sampling and analysis of residues was $20 \pm 0.5 \mathrm{mg}$. The pyrolytic reactions were stopped at some specific temperatures, e.g. $623,700,723$, and $938 \mathrm{~K}$, so as to collect the residues. The residues corresponding to these pyrolysis temperatures were then analyzed.

\subsection{Analysis}

The elemental analyses for the initial sample and the residues were made on a Perkin-Elmer, Norwalk, CT 2400 (with $0.3 \%$ accuracy) elemental analyzer. The heavy metals in the initial sample were analyzed by the inductively coupled plasma-atomic emission spectrometer (ICP-AES;
Table 1

Retention times of standards for determining the concentrations of $\mathrm{HCs}$

\begin{tabular}{|c|c|c|}
\hline Category & Compound & $\begin{array}{l}\text { Retention } \\
\text { time (min) }\end{array}$ \\
\hline Group 1 & $\begin{array}{l}\text { Methane } \\
\text { Ethylene } \\
\text { Ethane } \\
\text { Propylene } \\
\text { Propane }\end{array}$ & $\begin{array}{l}1.04 \\
1.04 \\
1.04 \\
1.09 \\
1.09\end{array}$ \\
\hline Group 2 & $\begin{array}{l}\text { Butene } \\
\text { Butane } \\
\text { Methanol }\end{array}$ & $\begin{array}{l}1.23 \\
1.24 \\
1.24\end{array}$ \\
\hline Group 3 & $\begin{array}{l}\text { Ethanol } \\
\text { Furan } \\
\text { Pentene } \\
\text { Pentane }\end{array}$ & $\begin{array}{l}1.42 \\
1.56 \\
1.59 \\
1.63\end{array}$ \\
\hline Group 4 & $\begin{array}{l}\text { Hexene } \\
\text { Hexane } \\
\text { Benzene } \\
\text { Butanol } \\
\text { Furfural } \\
\text { Isoamyl alcohol }\end{array}$ & $\begin{array}{l}2.61 \\
2.69 \\
4.1 \\
4.5 \\
4.98 \\
6.75\end{array}$ \\
\hline Group 5 & $\begin{array}{l}\text { Toluene } \\
n \text {-Heptane } \\
\text { 1-Octene } \\
\text { Octane } \\
\text { Xylene } \\
\text { Styrene } \\
\text { 1-Decene } \\
\text { Phenol } \\
n \text {-Nonane } \\
\text { Dodecene }\end{array}$ & $\begin{array}{r}7.6 \\
8.4 \\
9.9 \\
10.6 \\
11.5 \\
12.5 \\
12.7 \\
15.8 \\
16.2 \\
16.4\end{array}$ \\
\hline Group 6 & $\begin{array}{l}\text { Naphthalene }^{\mathrm{a}} \\
\text { Dodecane } \\
\text { Acenaphthylene }^{\mathrm{a}} \\
\text { Acenaphthene }^{\mathrm{a}}\end{array}$ & $\begin{array}{l}22.7 \\
23.1 \\
30.4 \\
31.3\end{array}$ \\
\hline Group 7 & Levoglucosan & 31.2 \\
\hline Group 8 & $\begin{array}{l}\text { Fluorene }^{\mathrm{a}} \\
\text { Phenanthrene }^{\mathrm{a}} \\
\text { Anthracene }^{\mathrm{a}}\end{array}$ & $\begin{array}{l}33.8 \\
38.6 \\
38.8\end{array}$ \\
\hline Group 9 & $\begin{array}{l}\text { Fluouanthene }^{\mathrm{a}} \\
\text { Pyrene }^{\mathrm{a}} \\
\text { Benzo(a)-anthracene }^{\mathrm{a}} \\
\text { Chrysene }^{\mathrm{a}}\end{array}$ & $\begin{array}{l}44.6 \\
45.8 \\
53 \\
53.4\end{array}$ \\
\hline
\end{tabular}

${ }^{a}$ The compounds are polycyclic aromatic hydrocarbons (PAHs).

Germany Kontron S-35). The mass of initial sample used for the analysis of heavy metals was $100 \mathrm{mg}$. The sample mixed with strong acids $\left(3 \mathrm{~cm}^{3} \mathrm{HNO}_{3}, 1 \mathrm{~cm}^{3}\right.$ $\mathrm{HClO}_{4}$, and $1 \mathrm{~cm}^{3} \mathrm{HF}$ ) was digested at $443 \mathrm{~K}$ for $4 \mathrm{~h}$. It was then diluted to $100 \mathrm{~cm}^{3}$ with pure $\mathrm{H}_{2} \mathrm{O}$ and analyzed by the ICP-AES

\section{Results and discussion}

\subsection{Solid residues}

Solid residues, at some specific extents of mass change, 
Table 2

Elemental analyses of initial sample and of residues for uncoated printing and writing paper pyrolysis at various temperatures (a: based on the mass of residues (dry basis); b: based on the mass of initial sample (dry basis))

\begin{tabular}{|c|c|c|c|c|c|c|c|c|c|c|}
\hline \multirow[t]{2}{*}{ Element (\%) } & \multicolumn{2}{|c|}{$300(\mathrm{~K})$} & \multicolumn{2}{|c|}{$623(\mathrm{~K})$} & \multicolumn{2}{|c|}{$700(\mathrm{~K})$} & \multicolumn{2}{|c|}{$723(\mathrm{~K})$} & \multicolumn{2}{|c|}{$938(\mathrm{~K})$} \\
\hline & $\mathrm{a}$ & $\mathrm{b}$ & $\mathrm{a}$ & $\mathrm{b}$ & $\mathrm{a}$ & $\mathrm{b}$ & $\mathrm{a}$ & $\mathrm{b}$ & $\mathrm{a}$ & $\mathrm{b}$ \\
\hline $\mathrm{C}$ & 34.65 & 34.65 & 36.09 & 24.19 & 30.9 & 10.79 & 31.94 & 10.59 & 36.2 & 7.81 \\
\hline $\mathrm{H}$ & 5.05 & 5.05 & 4.38 & 2.93 & 1.92 & 0.67 & 1.95 & 0.65 & 2.39 & 0.51 \\
\hline $\mathrm{O}$ & 43.84 & 43.84 & 36.07 & 24.17 & 23.56 & 8.23 & 16.71 & 5.54 & n.a. ${ }^{a}$ & n.a. \\
\hline $\mathrm{N}$ & 1.84 & 1.84 & 3.44 & 2.3 & n.d. ${ }^{b}$ & n.d. & 3.58 & 1.19 & n.d. & n.d. \\
\hline $\mathrm{S}$ & 0.25 & 0.25 & 1.43 & 0.96 & n.d. & n.d. & n.d. & n.d. & n.d. & n.d. \\
\hline $\mathrm{Cl}$ & 2.67 & 2.67 & 2.46 & 1.65 & n.d. & n.d. & n.d. & n.d. & n.d. & n.d. \\
\hline Total (\%) & 88.3 & 88.3 & 83.87 & 56.2 & 56.38 & 19.69 & 54.18 & 17.97 & 38.59 & 8.32 \\
\hline $\mathrm{C} / \mathrm{H}$ & 6.86 & 6.86 & 8.24 & 8.26 & 16.09 & 16.1 & 16.38 & 16.29 & 15.15 & 15.31 \\
\hline $\mathrm{C} / \mathrm{O}$ & 0.79 & 0.79 & 1 & 1 & 1.31 & 1.31 & 1.91 & 1.91 & & \\
\hline
\end{tabular}

a Not analyzed.

b Not detected.

were collected and analyzed by the elemental analyzer for determining the major elements and providing the evidence to support the pyrolysis mechanisms of two-reaction model [18]. The results of elemental analyses are summarized in Table 2. These results indicated that carbon (C), hydrogen $(\mathrm{H})$, and oxygen $(\mathrm{O})$ were the major constituents of solid residues. The $\mathrm{C} / \mathrm{H}$ mass ratios of solid residues were about $6.86,8.24,16.09,16.38$, and 15.15 at pyrolysis temperatures of $300,623,700,723$, and $938 \mathrm{~K}$, respectively. The $\mathrm{C} / \mathrm{O}$ mass ratios of solid residues were about $0.79,1.00,1.31$, and 1.91 at pyrolysis temperatures of $300,623,700$, and $723 \mathrm{~K}$, respectively. This indicated that the devolatilization reaction (first stage mass change) was significant from 500 to $625-680 \mathrm{~K}$ [18]. The products of this reaction stage were intermediates and low molecular mass volatiles (e.g. $\mathrm{H}_{2}$, $\mathrm{HCs}, \mathrm{H}_{2} \mathrm{O}$, etc.). This was also supported by the product distribution. The sulfur and chlorine in the residues were not detected at temperature, higher than $700 \mathrm{~K}$ (Table 2). It was noted that the sulfur and chlorine in the residue reacted to form $\mathrm{SO}_{x}$ and $\mathrm{HCl}$ in the first stage reaction. The $\mathrm{HCl}$ released at low temperature range $(<650 \mathrm{~K})$ was also observed in the similar studies [21-23] for the pyrolysis of polyvinyl chloride of MSW. In the second stage mass change (625-680 to $950 \mathrm{~K})$, the intermediates further reacted to form volatiles and solid residues. The mass percence of $\mathrm{C}$ based on the initial sample decreased from $24.19 \%$ (at $623 \mathrm{~K}$ ) to $7.81 \%$ (at $938 \mathrm{~K}$ ). This may be ascribed to the pyrolysis reactions and the gasification of $\mathrm{C}-\mathrm{CO}$ and $\mathrm{CO}_{2}$ at the second stage mass change. This was also observed in the gaseous products distributions. From the experimental results, the final residual mass was about
$21.55 \%$ of the initial sample. The moisture, ash, and combustible in the proximate analysis of the initial sample were about $1.26,12.8$, and $85.94 \%$, respectively. Based on the dry basis, the percentages of ash and combustible were calculated to be 12.96 and $87.04 \%$, respectively. Since the ash content was analyzed at $1073 \mathrm{~K}$ and in air environment. It was realized that the final residual mass percent was higher than that of ash in the proximate analysis. The inconsistent of ash and combustible contents in the proximate analysis with those in the ICP-AES analysis (Table 3) and elemental analysis (Table 2) might be ascribed to the non-uniformity of experimental sample.

\subsection{Gaseous products}

Qualitative analysis of gaseous products was carried out by GC/MS. The qualitative constituents of gaseous products were classified into nine groups according to the retention times of hydrocarbons. The retention times of standards for determining the concentrations of hydrocarbons are listed in Table 1 . The results indicated that there were some compounds observed in the retention time ranges of PAHs. This suggests that PAHs may be released in the pyrolysis or incomplete combustion process for treating waste uncoated printing and writing paper.

Quantitative analysis of gaseous products was analyzed by $\mathrm{GC} / \mathrm{FID}$ (for $\mathrm{HCs}$ ), $\mathrm{GC} / \mathrm{TCD}$ (for $\mathrm{H}_{2}, \mathrm{CO}, \mathrm{CO}_{2}$ ), and psychrometer (for $\mathrm{H}_{2} \mathrm{O}$ ). The concentrations of gaseous products were based on the calculation using the linear

Table 3

Principal metals in initial sample (dry basis)

\begin{tabular}{lllllllllllll}
\hline Species & $\mathrm{Si}$ & $\mathrm{Ca}$ & $\mathrm{Al}$ & $\mathrm{Mg}$ & $\mathrm{Fe}$ & $\mathrm{Cr}$ & $\mathrm{Mn}$ & $\mathrm{Zn}$ & $\mathrm{Cd}$ & $\mathrm{Tb}$ & & \\
\hline Conc. (ppmm) & 80,376 & 27,849 & 7242 & 15,555 & 2417 & 86 & 40 & $<10$ & $<10$ & $<10$ & 133,565 \\
\hline
\end{tabular}


Table 4

Variations of instantaneous concentrations of pyrolysis products with reaction temperature $(T)$ (a: Instantaneous concentrations ( $\mu g$ dm ${ }^{-3}$ ) of products produced at various reaction temperatures; b: Cumulated mass percent (\%) based on the initial sample (dry basis))

\begin{tabular}{|c|c|c|c|c|c|c|c|c|c|c|c|c|c|}
\hline \multirow[t]{2}{*}{$T(\mathrm{~K})$} & \multicolumn{2}{|l|}{$\mathrm{H}_{2}$} & \multicolumn{2}{|l|}{$\mathrm{CO}$} & \multicolumn{2}{|l|}{$\mathrm{CO}_{2}$} & \multicolumn{2}{|l|}{$\mathrm{H}_{2} \mathrm{O}$} & \multirow{2}{*}{$\begin{array}{l}\mathrm{HCs} \\
\mathrm{a}\end{array}$} & \multirow{2}{*}{$\begin{array}{l}\text { Gases } \\
\text { b }\end{array}$} & \multirow{2}{*}{$\begin{array}{l}\text { Residues } \\
\text { b }\end{array}$} & \multirow{2}{*}{$\begin{array}{l}\text { Recovery }^{\mathrm{a}} \\
\mathrm{b}\end{array}$} & \multirow{2}{*}{$\begin{array}{l}\operatorname{Tar}^{\mathrm{b}} \\
\mathrm{b}\end{array}$} \\
\hline & $\mathrm{a}$ & $\mathrm{b}$ & $\mathrm{a}$ & $\mathrm{b}$ & $\mathrm{a}$ & $\mathrm{b}$ & $\mathrm{a}$ & $\mathrm{b}$ & & & & & \\
\hline 488 & n.d. ${ }^{\mathrm{c}}$ & 0.00 & n.d. & 0.00 & n.d. & 0.00 & n.d. & 0.00 & 0.07 & 0.07 & 99.96 & 100.03 & 0.00 \\
\hline 513 & 9 & 0.01 & n.d. & 0.00 & 241 & 0.3 & 210 & 0.26 & 0.1 & 0.67 & 99.79 & 100.46 & 0.00 \\
\hline 538 & 14 & 0.03 & n.d. & 0.00 & 266 & 0.63 & 327 & 0.67 & 0.14 & 1.47 & 99.1 & 100.57 & 0.00 \\
\hline 563 & 16 & 0.05 & n.d. & 0.00 & 331 & 1.05 & 420 & 1.2 & 0.18 & 2.48 & 96.69 & 99.17 & 0.83 \\
\hline 588 & 16 & 0.07 & 146 & 0.18 & 802 & 2.05 & 607 & 1.95 & 0.23 & 4.48 & 89.72 & 94.2 & 5.8 \\
\hline 613 & 13 & 0.09 & 243 & 0.49 & 1817 & 4.32 & 980 & 3.18 & 0.36 & 8.44 & 74.85 & 83.29 & 16.71 \\
\hline 638 & 18 & 0.11 & 685 & 1.34 & 2418 & 7.34 & 1633 & 5.22 & 0.66 & 14.67 & 55.39 & 70.06 & 29.94 \\
\hline 663 & 24 & 0.14 & 1181 & 2.82 & 2738 & 10.76 & 2100 & 7.85 & 0.77 & 22.34 & 41.79 & 64.13 & 35.87 \\
\hline 688 & 31 & 0.18 & 1260 & 4.39 & 3013 & 14.53 & 1843 & 10.15 & 0.83 & 30.08 & 36.2 & 66.28 & 33.72 \\
\hline 713 & 29 & 0.21 & 1041 & 5.7 & 4450 & 20.09 & 1563 & 12.1 & 0.95 & 39.05 & 33.89 & 72.94 & 27.06 \\
\hline 738 & 21 & 0.24 & 1029 & 6.98 & 4044 & 25.15 & 1342 & 13.78 & 0.98 & 47.13 & 31.99 & 79.12 & 20.88 \\
\hline 763 & 15 & 0.26 & 1372 & 8.7 & 4654 & 30.97 & 1248 & 15.34 & 1.02 & 56.29 & 29.74 & 86.03 & 13.97 \\
\hline 788 & 12 & 0.27 & 1619 & 10.72 & 4533 & 36.63 & 1248 & 16.9 & 1.05 & 65.57 & 27.39 & 92.96 & 7.04 \\
\hline 813 & 18 & 0.3 & 525 & 11.38 & 3840 & 41.63 & 1260 & 18.48 & 1.07 & 72.86 & 25.38 & 98.24 & 1.76 \\
\hline 838 & 14 & 0.31 & 180 & 11.6 & 1456 & 43.45 & 1330 & 20.14 & 1.16 & 76.66 & 23.93 & 100.59 & 0.00 \\
\hline 863 & 9 & 0.33 & 814 & 12.62 & 744 & 44.38 & n.a. ${ }^{d}$ & 20.14 & 1.28 & 78.75 & 23 & 101.75 & 0.00 \\
\hline 888 & n.d. & 0.33 & 345 & 13.05 & 592 & 45.12 & n.a. & 20.14 & 1.39 & 80.03 & 22.43 & 102.46 & 0.00 \\
\hline 913 & n.d. & 0.33 & 173 & 13.27 & 192 & 45.36 & n.a. & 20.14 & 1.5 & 80.6 & 21.99 & 102.59 & 0.00 \\
\hline 938 & n.d. & 0.33 & n.d. & 13.27 & n.a. & 45.36 & n.a. & 20.14 & 1.63 & 80.73 & 21.55 & 102.28 & 0.00 \\
\hline
\end{tabular}

${ }^{\mathrm{a}}$ Recovery $=$ gases + residues.

b Tar $=100 \%-$ recovery, set to zero if value is negative.

c Not detected.

d Not analyzed.

calibration response equations of standards. The equation was generated for each of gas and liquid standards using a minimum of five different concentrations with three replicates at each concentration. All correlation coefficients $\left(r^{2}\right)$ of linear calibration response curves were great than 0.997 . Since the pyrolysis products consisted of lots of hydrocarbon species. The hydrocarbons were not quantified one by one except levoglucosan and $\mathrm{C}_{1}-\mathrm{C}_{5}$ alkanes. The concentration of each group (except levoglucosan and $\mathrm{C}_{1}-$ $\mathrm{C}_{5}$ alkanes) was determined by calculating the areaconcentration ratios of the gaseous products corresponding retention time range. The analyses of instantaneous concentrations and of cumulated masses of gaseous products corresponding to the various temperature ranges are listed in Tables 4-6. The results indicated that the amount of gaseous products was negligible for temperatures lower than $488 \mathrm{~K}$. The maximum instantaneous concentrations occurred at about $688 \mathrm{~K}$ for $\mathrm{H}_{2}, 788 \mathrm{~K}$ for $\mathrm{CO}, 763 \mathrm{~K}$ for $\mathrm{CO}_{2}, 663 \mathrm{~K}$ for $\mathrm{H}_{2} \mathrm{O}$, and $638 \mathrm{~K}$ for $\mathrm{HCs}$, respectively. On examining the TGA curves [18], there were two principal reactions as distinguished by the two significant and distinct mass changes over the temperature range of $450-950 \mathrm{~K}$. In the preceding section, it was noted that the release of low molecular mass compounds $\left(\mathrm{H}_{2}, \mathrm{HCs}, \mathrm{H}_{2} \mathrm{O}\right.$, etc.) was significant from 500 to $625-680 \mathrm{~K}$, while that of volatiles $(\mathrm{CO}$, $\mathrm{CO}_{2}, \mathrm{HCs}$, etc.) by gasification reaction or further pyrolysis of intermediates was significant from $625-680$ to $950 \mathrm{~K}$. Thus, it was supported by the analysis of instantaneous concentrations at various reaction temperature ranges. The cumulated masses (at $938 \mathrm{~K}$ ) of major products relative to the initial sample were $0.33 \%$ for $\mathrm{H}_{2}, 13.27 \%$ for $\mathrm{CO}$, $45.36 \%$ for $\mathrm{CO}_{2}, 20.14 \%$ for $\mathrm{H}_{2} \mathrm{O}$, and $1.63 \%$ for hydrocarbons, respectively. The percentages (at $938 \mathrm{~K}$ ) of major hydrocarbons relative to the total $\mathrm{HCs}$ gases were about $17.8 \%$ for group $1\left(\mathrm{C}_{1-3}\right), 13.5 \%$ for group $3\left(\mathrm{C}_{5}\right)$, and $50.3 \%$ for group 7 (levoglucosan), respectively. Levoglucosan was the major compound of hydrocarbons. The yields of non-hydrocarbon gases and of hydrocarbon gases were about 10.46 and $0.49 \%$ at $623 \mathrm{~K}, 33.68$ and $0.89 \%$ at $700 \mathrm{~K}, 64.52$ and $1.05 \%$ at $788 \mathrm{~K}$, and 79.10 and $1.63 \%$ at

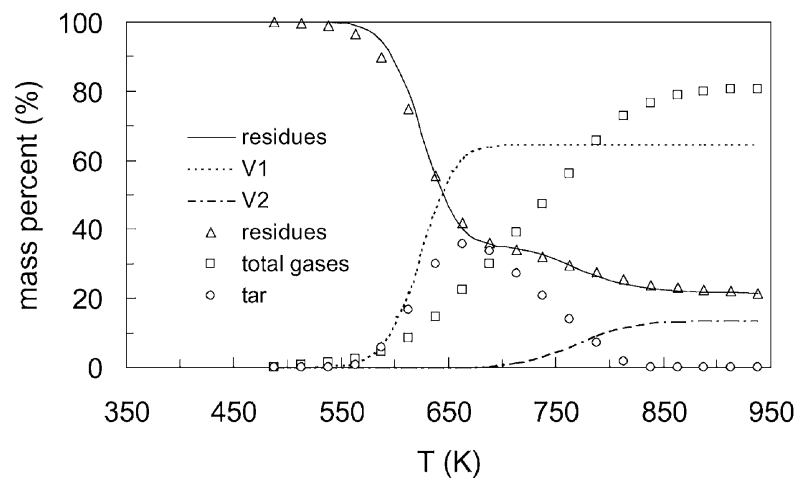

Fig. 1. Mass percents of residues and cumulated products at various reaction temperatures. Line: computed; symbol: experimental. 
Table 5

Variations of instantaneous concentrations of HCs with reaction temperature $(T)$ (a: instantaneous concentrations $\left(\mu \mathrm{g} \mathrm{dm}^{-3}\right.$ ) of $\mathrm{HCs}$ produced at various reaction temperatures; b: cumulated mass percent (\%) based on the initial sample (dry basis))

\begin{tabular}{|c|c|c|c|c|c|c|c|c|c|c|c|}
\hline$T(\mathrm{~K})$ & & Group 1 & Group 2 & Group 3 & Group 4 & Group 5 & Group 6 & Group 7 & Group 8 & Group 9 & Total \\
\hline \multirow[t]{2}{*}{488} & $\mathrm{a}$ & 0.54 & 0.43 & 3.19 & n.d. ${ }^{a}$ & n.d. & 4.95 & 46.75 & 0.38 & n.d. & 56.24 \\
\hline & $\mathrm{b}$ & 0.00 & 0.00 & 0.00 & 0.00 & 0.00 & 0.01 & 0.06 & 0.00 & 0.00 & 0.07 \\
\hline \multirow[t]{2}{*}{513} & $\mathrm{a}$ & 0.87 & 1.52 & 0.22 & 0.67 & 0.92 & 1.13 & 24.81 & 0.48 & n.d. & 30.64 \\
\hline & $\mathrm{b}$ & 0.00 & 0.00 & 0.00 & 0.00 & 0.00 & 0.01 & 0.09 & 0.00 & 0.00 & 0.1 \\
\hline \multirow[t]{2}{*}{538} & $\mathrm{a}$ & 1.06 & 0.3 & 0.69 & n.d. & n.d. & 1.59 & 23.17 & n.d. & 0.14 & 26.95 \\
\hline & $\mathrm{b}$ & 0.00 & 0.00 & 0.01 & 0.00 & 0.00 & 0.01 & 0.12 & 0.00 & 0.00 & 0.14 \\
\hline \multirow[t]{2}{*}{563} & $\mathrm{a}$ & 1.15 & 0.47 & 0.22 & n.d. & n.d. & 1.6 & 22.25 & 3.87 & 0.73 & 30.29 \\
\hline & $\mathrm{b}$ & 0.00 & 0.00 & 0.01 & 0.00 & 0.00 & 0.01 & 0.15 & 0.01 & 0.00 & 0.18 \\
\hline \multirow[t]{2}{*}{588} & $\mathrm{a}$ & 1.09 & n.d. & 4.22 & 2.29 & n.d. & 4.13 & 25.25 & 3.28 & 2.07 & 42.33 \\
\hline & $\mathrm{b}$ & 0.01 & 0.00 & 0.01 & 0.00 & 0.00 & 0.02 & 0.18 & 0.01 & 0.00 & 0.23 \\
\hline \multirow[t]{2}{*}{613} & $\mathrm{a}$ & 2.62 & 3.71 & 15.34 & 15.06 & 2.65 & 3.89 & 59.83 & 4.61 & 0.67 & 108.38 \\
\hline & $\mathrm{b}$ & 0.01 & 0.01 & 0.03 & 0.02 & 0.00 & 0.02 & 0.25 & 0.02 & 0.00 & 0.36 \\
\hline \multirow[t]{2}{*}{638} & $\mathrm{a}$ & 10.79 & 12.45 & 111.25 & 39.83 & 6.62 & 3.96 & 55 & 1.76 & 0.21 & 241.87 \\
\hline & $\mathrm{b}$ & 0.02 & 0.02 & 0.17 & 0.07 & 0.01 & 0.03 & 0.32 & 0.02 & 0.00 & 0.66 \\
\hline \multirow[t]{2}{*}{663} & $\mathrm{a}$ & 4.77 & 3.68 & 3.17 & 3.24 & 3.79 & 2.96 & 47.08 & 3.19 & 0.25 & 72.13 \\
\hline & $\mathrm{b}$ & 0.03 & 0.03 & 0.17 & 0.08 & 0.02 & 0.03 & 0.38 & 0.02 & 0.01 & 0.77 \\
\hline \multirow[t]{2}{*}{688} & $\mathrm{a}$ & 1.53 & 0.21 & 0.46 & 2.53 & n.d. & 2.64 & 42.19 & 2.92 & 0.88 & 53.36 \\
\hline & $\mathrm{b}$ & 0.03 & 0.03 & 0.17 & 0.08 & 0.02 & 0.03 & 0.43 & 0.03 & 0.01 & 0.83 \\
\hline \multirow[t]{2}{*}{713} & $\mathrm{a}$ & 13.95 & 2.75 & 1.55 & 0.59 & n.d. & 2.39 & 62.88 & 5.86 & 0.97 & 90.94 \\
\hline & $\mathrm{b}$ & 0.05 & 0.03 & 0.18 & 0.08 & 0.02 & 0.04 & 0.51 & 0.03 & 0.01 & 0.95 \\
\hline \multirow[t]{2}{*}{738} & $\mathrm{a}$ & 1.45 & 0.26 & n.d. & n.d. & n.d. & 1.67 & 21.63 & n.d. & n.d. & 25.01 \\
\hline & $\mathrm{b}$ & 0.05 & 0.03 & 0.18 & 0.08 & 0.02 & 0.04 & 0.54 & 0.03 & 0.01 & 0.98 \\
\hline \multirow[t]{2}{*}{763} & $\mathrm{a}$ & 2.7 & 0.73 & n.d. & n.d. & 0.27 & 0.51 & 30.88 & n.d. & n.d. & 35.09 \\
\hline & $\mathrm{b}$ & 0.05 & 0.03 & 0.18 & 0.08 & 0.02 & 0.04 & 0.58 & 0.03 & 0.01 & 1.02 \\
\hline \multirow[t]{2}{*}{788} & $\mathrm{a}$ & 0.48 & 0.09 & 0.04 & n.d. & n.d. & 0.03 & 24 & n.d. & n.d. & 24.64 \\
\hline & $\mathrm{b}$ & 0.05 & 0.03 & 0.18 & 0.08 & 0.02 & 0.04 & 0.61 & 0.03 & 0.01 & 1.05 \\
\hline \multirow[t]{2}{*}{813} & $\mathrm{a}$ & 6.09 & n.d. & n.d. & 0.55 & n.d. & 1.42 & 12.88 & 0.8 & n.d. & 21.74 \\
\hline & $\mathrm{b}$ & 0.06 & 0.03 & 0.18 & 0.08 & 0.02 & 0.04 & 0.62 & 0.03 & 0.01 & 1.07 \\
\hline \multirow[t]{2}{*}{838} & $\mathrm{a}$ & 6.29 & 1.48 & 4.24 & 13.6 & 0.85 & 4.02 & 26.13 & 0.16 & 0.5 & 57.27 \\
\hline & $\mathrm{b}$ & 0.07 & 0.04 & 0.18 & 0.1 & 0.02 & 0.05 & 0.66 & 0.03 & 0.01 & 1.16 \\
\hline \multirow[t]{2}{*}{863} & $\mathrm{a}$ & 42.18 & 3.05 & 4.74 & 2.49 & n.d. & 1.71 & 45.63 & 2.21 & 1.27 & 103.28 \\
\hline & $\mathrm{b}$ & 0.12 & 0.04 & 0.19 & 0.1 & 0.02 & 0.05 & 0.71 & 0.04 & 0.01 & 1.28 \\
\hline \multirow[t]{2}{*}{888} & $\mathrm{a}$ & 40.6 & 3.98 & 6.46 & 3.87 & 0.34 & 3.04 & 35.63 & 1.48 & 0.69 & 96.09 \\
\hline & $\mathrm{b}$ & 0.17 & 0.04 & 0.19 & 0.11 & 0.02 & 0.05 & 0.76 & 0.04 & 0.01 & 1.39 \\
\hline \multirow[t]{2}{*}{913} & $\mathrm{a}$ & 39.02 & 4.92 & 8.18 & 5.26 & 0.68 & 4.37 & 25.62 & 0.74 & 0.12 & 88.91 \\
\hline & $\mathrm{b}$ & 0.22 & 0.05 & 0.2 & 0.11 & 0.02 & 0.06 & 0.79 & 0.04 & 0.01 & 1.5 \\
\hline \multirow[t]{2}{*}{938} & $\mathrm{a}$ & 52.7 & 6.11 & 9.4 & 1.56 & 0.53 & 4.22 & 27.63 & 1.14 & 0.09 & 103.38 \\
\hline & $\mathrm{b}$ & 0.29 & 0.06 & 0.22 & 0.11 & 0.02 & 0.06 & 0.82 & 0.04 & 0.01 & 1.63 \\
\hline
\end{tabular}

${ }^{\text {a }}$ Not detected.

$938 \mathrm{~K}$, respectively. The results indicated that the nonhydrocarbons were the major gaseous products.

\subsection{Mass balance}

The mass percents of residues and cumulated gaseous products at various reaction temperatures, as shown in Fig. 1, were obtained by the two-reaction model [18] and in this study. According to the proposed model [18], the decrease of the residual mass percent at the first reaction stage (below $680 \mathrm{~K}$ ) was about $64.72 \%$. However, the cumulated mass of the gaseous products was only $30.08 \%$ at $683 \mathrm{~K}$ as shown in Table 4. One may reasonably assume that the volatile $V_{1}$ (in two-reaction model) released at this stage consisted of gaseous products and liquid tar. The instantaneous and cumulated gaseous quantities were directly obtained from the sampling site. The amount of liquid products (tar) can be estimated from the balance of the experimental quantities of solid residues and gaseous products. This then provided the distributions of solid residues, liquid products (tar), and gaseous products under different temperatures as shown in Tables $4-6$ and Fig. 1 . The maximum rate of tar released occurred at about $663 \mathrm{~K}$. It was further pyrolyzed to light components at high temperature range. Also, the decrease of the residual mass percent in the second-stage reaction $(680-950 \mathrm{~K})$ was about $13.76 \%$. The volatiles $V_{2}$ (in two-reaction model) were the major products. The product distributions are determined in this study and listed in Tables 4 and 5. It is noted that the mass percent of the total gases from the experimental work was equal to the summation of the masses of volatiles $V_{1}$ and $V_{2}$ by the proposed model. The results in Fig. 1 indicate that the two-reaction model gives a good agreement with the experimental data. 
Table 6

Cumulated mass percents (\%) of various products relative to initial sample (dry basis) at some significant temperatures

\begin{tabular}{lcccc}
\hline Product & $623(\mathrm{~K})$ & $700(\mathrm{~K})$ & $788(\mathrm{~K})$ & $938(\mathrm{~K})$ \\
\hline $\mathrm{H}_{2}$ & 0.1 & 0.2 & 0.27 & 0.33 \\
$\mathrm{CO}$ & 0.83 & 5.04 & 10.72 & 13.27 \\
$\mathrm{CO}_{2}$ & 5.53 & 17.31 & 36.63 & 45.36 \\
$\mathrm{H}_{2} \mathrm{O}$ & 4 & 11.13 & 16.9 & 20.14 \\
Group 1 & 0.01 & 0.04 & 0.05 & 0.29 \\
Group 2 & 0.01 & 0.03 & 0.03 & 0.06 \\
Group 3 & 0.09 & 0.17 & 0.18 & 0.22 \\
Group 4 & 0.04 & 0.08 & 0.08 & 0.11 \\
Group 5 & 0.01 & 0.02 & 0.02 & 0.02 \\
Group 6 & 0.02 & 0.03 & 0.04 & 0.06 \\
Group 7 & 0.29 & 0.48 & 0.61 & 0.82 \\
Group 8 & 0.02 & 0.03 & 0.03 & 0.04 \\
Group 9 & 0.00 & 0.01 & 0.01 & 0.01 \\
Non-HC gases & 10.46 & 33.68 & 64.52 & 79.1 \\
HC ${ }_{x}$ gases & 0.49 & 0.89 & 1.05 & 1.63 \\
Gases & 10.95 & 34.57 & 65.57 & 80.73 \\
Residues & 67.06 & 35.04 & 27.39 & 21.55 \\
Gases and residues & 78.01 & 69.61 & 92.96 & 102.28 \\
Estimated tar & 21.99 & 30.39 & 7.04 & 0 \\
& & & &
\end{tabular}

${ }^{\mathrm{a}} \mathrm{Tar}=100 \%-(\mathrm{gas}+$ residues $)$, set to zero if value is negative.

\section{Conclusions}

Pyrolysis experiments of the uncoated printing and writing paper were carried out in a TGA reaction system at a constant heating rate of $5 \mathrm{~K} \mathrm{~min}^{-1}$ and in a nitrogen environment. The gaseous products and the residues were collected at room temperature $(300 \mathrm{~K})$ and analyzed by gas chromatography and elemental analyzer, respectively. The major gaseous products investigated included non-hydrocarbons $\left(\mathrm{H}_{2}, \mathrm{CO}, \mathrm{CO}_{2}\right.$, and $\left.\mathrm{H}_{2} \mathrm{O}\right)$ and hydrocarbons $\left(\mathrm{C}_{1}-\right.$ $\mathrm{C}_{3}, \mathrm{C}_{4}, \mathrm{C}_{5}, \mathrm{C}_{6}$, 1-ring, $\mathrm{C}_{10}-\mathrm{C}_{12}$, levoglucosan, $\mathrm{C}_{13}-\mathrm{C}_{15}$, and $\left.\mathrm{C}_{16}-\mathrm{C}_{18}\right)$. The cumulated masses and the instantaneous concentrations of gaseous products were obtained under the experimental conditions. The yields of non-hydrocarbon gases and of hydrocarbons were about 10.46 and $0.49 \%$ at $623 \mathrm{~K}, 33.68$ and $0.89 \%$ at $700 \mathrm{~K}, 64.52$ and $1.05 \%$ at $788 \mathrm{~K}$, and 79.10 and $1.63 \%$ at $938 \mathrm{~K}$, respectively. Since the synthetic gases $\left(\mathrm{CO}, \mathrm{CO}_{2}, \mathrm{H}_{2} \mathrm{O}, \mathrm{HCs}\right)$ contained a high calorific value, their use as marketable fuels greatly supported the importance for resource recycling of the uncoated printing and writing paper. As the main compo- nents in the residues, the utilization of silicon and/or silica may be also attractive.

\section{Acknowledgements}

We express our sincere thanks to the National Science Council of Taiwan for the financial support under projects NSC 85-2211-E-212-001 and also would like to thank the Yuen Foong Yu Co., Ltd, of Taiwan, for providing the uncoated printing and writing sample.

\section{References}

[1] Hoffman DA, Fitz RA. Environ Sci Technol 1968;2:1023.

[2] Buekens AG, Schoeters JG. Conserv Recycling 1986;9:253.

[3] Aroguz AZ, Onsan ZI. Chim Acta Tur 1987;15:415.

[4] Levie B, Diebold JP, West R. In: Bridgwater AV, Kuester JL, editors. Research on thermochemical biomass conversion. London: Elsevier, 1988. p. 312-26.

[5] Mallya N, Helt JE, Proceedings of the 13th National Waste Process Conference, USA. 1988. p. 295-300.

[6] Diebold J, Evans R, Scabill J. Energy Biom Wastes 1990;13:851.

[7] Yang WF, An engineering project for garbage incineration plant of Taipei City: sampling and analyses of garbage at 13th year. Report of Environmental Protection Bureau of Taipei City, Taiwan, ROC, 1996.

[8] Fairbridge C, Ross RA, Sood SP. J Appl Polym Sci 1978;22:497.

[9] Shafizadeh F, Bradbury AGW. J Appl Polym Sci 1979;23:1431.

[10] Antal MJ, Friedman Jr HL, Rogers FE. Combust Sci Technol 1980;21:141.

[11] Simkovic I, Durindova M, Mihalov V, Konigstein J. J Appl Polym Sci 1986;31:2433.

[12] Calahorra ME, Cortazar M, Eguiazabal JI, Guzman GM. J Appl Polym Sci 1989;37:3305

[13] Gullett BK, Smith P. Combust Flame 1987;67:143.

[14] Bradbury AGW, Sakai Y, Shafizadeh F. J Appl Polym Sci 1979;23:3271.

[15] Agrawal RK. Can J Chem Engng 1988;66:403.

[16] Agrawal RK. Can J Chem Engng 1988;66:413.

[17] Kilzer FJ, Broido A. Pyrodynamics 1965;2:151.

[18] Chang CY, Wu CH, Hwang JY, Lin JP, Yang WF, Shih SM, Chen LW, Chang FW. J Environ Engng 1996;122:299.

[19] Rogers FE, Ohlemiller TJ. Combust Sci Technol 1980;24:129.

[20] Agrawal RK, McCluskey RJ. J Appl Polym Sci 1983;27:367.

[21] Wu CH, Chang CY, Hor JL, Shih SM, Chen LW, Chang FW. Waste Mgmt 1993;13:221.

[22] Wu CH, Chang CY, Hor JL, Shih SM, Chen LW, Chang FW. Can J Chem Engng 1994;72:644.

[23] Wu CH, Liang Y. J Environ Engng 2001;127(1):70. 